\title{
Connectivity, Clientelism and Public Provision
}

\author{
Mahvish Shami \\ London School of Economics and Political Science \\ British Journal of Political Science (Forthcoming)
}

\begin{abstract}
In many developing countries the rural poor often depend on patrons to act as brokers in order to get public provision from the government. The broker facilitates provision in return for securing peasants' votes for politicians. Yet, low bargaining power of peasants allows patrons to appropriate public resources for themselves. I propose increasing peasants' bargaining power by connecting them to markets outside their village. Making use of a natural experiment found in the construction of a motorway in Pakistan, I find public provision to be significantly higher in connected villages when compared to those isolated. Moreover, I find that the beneficial impact of connectivity is felt most strongly by the lower classes, who are most vulnerable to exploitation when isolated.
\end{abstract}

Literature on economic development places considerable emphasis on state provision as a means of enhancing the welfare of the poor and reducing inequality. ${ }^{1}$ Despite this concern, however, in many developing countries public funds are often channelled through local 'elites', rather than directly reaching the poor. ${ }^{2}$ One reason for the reliance on local elites is that democratic

\footnotetext{
${ }^{1}$ Public provision here refers to any good or service provided by the government to its citizens. This could be in the form of private, club or public goods. It can be universal or highly targeted provision. I use the terms public provision and state provision interchangeably.

${ }^{2}$ This holds in countries with democratic and semi-democratic institutions. See for example Medina and Stokes 2007; Kitschelt and Wilkinson 2007; Fox 1994; Auyero 2000; Brusco et al. 2002; Levitsky 2001;
} 
institutions in developing countries are often young and unreliable, thereby restricting politicians' ability to make credible pre-election promises. $^{3}$ Attempts to mitigate this disadvantage often involves politicians approaching local people of influence to act as brokers with poor constituents, thus leading to the establishment of an exchange relationship where politicians offer material benefits to local elites - meant for both elites and their clients - in exchange for political support.

There is significant evidence on this form of 'political clientelism' in many developing countries. ${ }^{4}$ Rather than looking at dyadic patron-client relationships, as in traditional work on clientelism, ${ }^{5}$ this literature focuses on the triadic relationship between politicians and their poorest constituents through the mediating role played by brokers. Here, politicians are patrons for local elites by providing access to public resources in exchange for political support, whereas local elites are patrons for the poor and can act as brokers to allow their clients access to resources from politicians. These networks can be so pervasive that Auyero notes how political clientelism takes centre stage in most studies on political engagement of the poor. ${ }^{6}$

An important implication of these networks is that the poor are dependent on aligning with someone of influence in order to benefit from public provision. However, aligning with an influential does not guarantee public provision. As Stoke et al. note, brokers yield considerable power in their local community and engage in this relationship with the intention of extracting Roniger 2004 for a more recent take on the literature. A good compilation on the older works on clientelism can be found in Schmidt et al. 1977.

${ }^{3}$ See generally, Keefer 2007.

${ }^{4}$ This is a generalised definition of political clientelism. See Stokes et al. 2013 for a good overview of the literature. See also the references in footnote 1. As Medina and Stokes 2002 and Roniger 2004 note, there is no agreed definition of clientelism, resulting in considerable variation and debates regarding the concept. This paper does not attempt to add to this debate and therefore uses a relatively broad definition.

${ }^{5}$ For classic works on clientelism, see particularly Scott 1977 and Powell 1970.

${ }^{6}$ Auyero1999. While a considerable portion of the literature on political clientelism focuses on Latin America, it can be applied, with some variation, to most developing countries. 
benefits. $^{7}$ Therefore, where possible, they will try to appropriate resources from the government for their own private use rather than channelling them to their clients. In extreme cases of exploitation, brokers manage to appropriate most public resources for themselves in exchange for delivering clients’ votes to politicians. ${ }^{8}$

The question then is: why do the poor allow brokers to appropriate funds secured on the bases of their votes? While the literature on political clientelism has extensively analysed the relationship between politicians and local influentials, there is limited understanding of the relationship between local influentials and their clients. ${ }^{9}$ In particular, there is little systematic evidence on how local influentials distribute public resources placed at their disposal and what factors influence the chances of poor households’ receiving public funds.

This paper starts to fill this gap in a rural setting, where patrons are the local landlords and clients are peasants. As others before me, I draw attention to the inelasticity of demands that peasants make from landlords and how asymmetric bargaining power enables patrons to appropriate public resources for their own use when acting as brokers between the poor and the government. And whereas traditional solutions to this exploitative exchange have focused on redistribution, ${ }^{10}$ this paper draws inspiration from Basu's seminal work on rural monopoly power where he argues that landlords' ability to exploit peasants stems not from inequality alone, but from the interaction of inequality with isolation. It is the interaction of the two that results in particularly exploitative forms of clientelism. ${ }^{11}$ To use the framework of Hirschman, clientelism can thereby be seen as an

\footnotetext{
${ }^{7}$ Stokes at al. 2013. See also Camp 2012.

${ }^{8}$ Author 2012b; Keefer 2004; Powell 1970; Scott and Kerkvliet 1977.

${ }^{9}$ Auyero (1999) commented how, at that time, the literature made limited attempts to add to our understanding of how clientelism worked at the grassroots. Since then few studies have attempted to do this. Susan Stokes and Anund Krishna are two of the main contributors in this field.

${ }^{10}$ Ranging from policies such as progressive taxes, to welfare schemes and to land reforms, these tend to be contentious and thus difficult to implement (Herring 2005).

${ }^{11}$ Basu 1986.
} 
institution which "arouses but ignores voice while it would be responsive to exit". ${ }^{12}$ This means that clients need effective 'exit' options in order to make patrons more responsive to 'voice' when brokering public provision.

This paper studies one such exit option: opening up a village to the wider economy. Reducing isolation should alter relative bargaining powers, thereby increasing the competition that landlords face for the services provided by peasants. While there are a number of ways to achieve this, I explore the effect that connectivity, through road networks, has on previously isolated rural economies. Previous work has shown that connectivity increases bargaining power of peasants ${ }^{13}$ and, for that reason, reduces the ability of local patrons to block collective action among peasants. ${ }^{14}$ By the same logic, connectivity should also force local patrons to offer their clients increased public provision if they want to maintain their influence in the rural economy. ${ }^{15}$

Making use of a natural experiment in the form of a motorway constructed in Pakistan in 1998, this paper demonstrates that while public resources are always channelled through local brokers, provision to the poor is higher in villages connected to the external market. Unlike in isolated villages, patrons in villages close to the motorway can no longer demand clients' political loyalty without delivering significant public provision in return.

The remainder of the paper is organised as follows: Section 1 briefly describes a typical politician-landlord-peasant network, focusing in particular on the low bargaining power of peasants vis-à-vis their landlord in the presence of inequality and isolation and how that influences political outcomes. Section 2 tests the theoretical framework using data from rural Pakistan to evaluate the

\footnotetext{
${ }^{12}$ Hirschman 1970, 123. I would like to thank Lauge Poulsen for highlighting the relevance of Hirchman's theory for this study.

${ }^{13}$ Author 2012a.

${ }^{14}$ Author 2012b.

${ }^{15}$ Scott and Kerkvliet (1977) argue that any change in the environmental setting of the relationship should result in a re-working of the terms of exchange so as to ensure that the relationship remains mutually beneficial.
} 
impact of connectivity on clientelist networks. The analysis makes use of four types of villages varying based on their distance from the motorway (close v. far) and levels of inequality (landlord dominated v. egalitarian). I find that, while in isolation, public spending is significantly lower in villages dominated by large landlords when compared to relatively egalitarian ones. However, once connected to the external economy, outcomes in the differently tenured villages converge to the benefit of the rural poor. Section 3 concludes.

\section{Politician-Broker-Peasant Networks and Public Provision}

In many developing countries state failure, coupled with inequality, has meant that the poor are forced to approach local elites in order to satisfy many of their basic needs. This is particularly true in rural economies, where the problem is exacerbated by lack of access to markets. Often this has resulted in the establishment of clientelist relationships. Born out of necessity and mutual benefit, these are relationships between groups of unequals. ${ }^{16}$ On the one hand the network consists of the local patron - typically a landlord - with command over resources which he can offer to clients - typically peasants - to satisfy their economic, social and political needs. ${ }^{17}$ Clients, on the other hand, own few assets and are therefore vulnerable to fluctuations in their environment. ${ }^{18}$ In exchange for access to the patron's resources they offer him a reliable source of cheap labour, ${ }^{19}$ add

\footnotetext{
${ }^{16}$ Mason 1986; Powell 1970; Scott and Kerkvliet 1977.

${ }^{17}$ These range from goods and services such as housing, employment, credit, dispute resolution, protection from exploitation and access to government officials and resources. See Bardhan 1980 for a good overview. ${ }^{18}$ Powell 1970.

${ }^{19}$ In an agrarian economy, where the demand for labour tends to be seasonal, a reliable source of workers is very valuable during harvesting and sowing seasons.
} 
to his social standing and, most importantly for this paper, offer political support by agreeing to vote in accordance with the wishes of the landlord. ${ }^{20}$

The rate at which these goods and services are reciprocated is determined by relative bargaining powers. By definition, of course, the patron has the upper hand as the needs of the assetpoor clients tend to be relatively inelastic, while those of the patron are desired but by no means life threatening. ${ }^{21}$ Peasants, while having significant value for the patron in the aggregate face a classic collective action problem due to which their individual value remains low. ${ }^{22}$ The bargaining power of an individual peasant depends on the needs he aims to fulfil through the patron, the number of other clients with whom he has to compete for patronage and the amount of alternatives he has for fulfilling his needs. Thus, clients who are economically independent can negotiate better terms from the exchange, whereas poor and destitute clients may receive little more than subsistence. ${ }^{23}$

One of the services that landlords demand from peasants is a guarantee that they will vote in accordance with their political preferences. Once promised clients are unable to renege on their commitment as the close-knit nature of small towns and villages in developing countries often makes it unlikely for voting decisions to remain hidden, and non-compliant behaviour would be reported by operatives. ${ }^{24}$ Mason and Joshi argue that this holds true even in the presence of formal assurances by the government of ballot secrecy, as clients have no precedence of secret balloting and therefore, have no reason to believe such assurances. ${ }^{25}$ This gives the landlord control over a

\footnotetext{
${ }^{20}$ Scott and Kerkviet 1977. See also Ahmad 1977; Rouse 1988; Scott and Kerkvliet 1977, Powell 1970, Auyero 1999.

${ }^{21}$ Eisenstadt and Roniger 1980.

${ }^{22}$ Mason 1986.

${ }^{23}$ Waterbury 1977.

${ }^{24}$ Stokes 2004. My own experience doing field research was similar. Villagers thought of voting as a communal activity, carried out based on consultations with fellow peasants and under the direction of the local landlord.

${ }^{25}$ Mason and Joshi 2008.
} 
vote base that he can trade with politicians in exchange for access to public resources. These resources are used both to improve his own well-being and to strengthen his patronage network by offering 'rewards' to those peasants who have relatively stronger bargaining power within the network. The result is the establishment of the politician-broker-peasant relationship, where the local landlord acts as the middleman between politicians and their rural constituents.

There are clear benefits for politicians to engage in this relationship. Firstly, as politicians are often unable to make credible electoral promises in young democracies, they need to align with someone whose promises voters believe. Local patrons, because of their face to face dealings with peasants, are able to offer this service. ${ }^{26}$ Secondly, local patrons have significant information about local needs, which is useful when politicians engage in non-programmatic distribution. ${ }^{27}$ Thirdly, contracting with local patrons is 'cheaper' than expending public resources towards the masses, as the number of people that the politician needs to satisfy shrinks from a winning majority of constituents to a winning majority of brokers. ${ }^{28}$ Finally, securing votes through local patrons is more likely to yield electoral results than campaigning, as defection on the part of the landlord is often detectable due to the large number of votes he controls. ${ }^{29}$

In short, the politician-broker-peasant network is beneficial for both politicians, who get access to a guaranteed vote base, and local patrons, who gain control over state resources. While

\footnotetext{
${ }^{26}$ Keefer and Vlaicu 2008

${ }^{27}$ Stokes et al 2013.

${ }^{28}$ Mason and Joshi 2008. The terms of the exchange between politicians and local patrons are determined through a bargaining game. The strength of each party depends on factors such as the number of votes the patron is offering, the politicians' standing in the upcoming election and the relative social and economic status of the two. This bargaining game has been studied extensively, but is outside the scope of this paper. See footnote 1 for references.

${ }^{29}$ Fox 1994; Powell 1970; Scott1972. This is contrasted by contracting with citizens who, by virtue of constituting a minute fraction of the voting body, have a higher chance of reneging (mostly by choosing not to vote) without detection by the politician (Keefer 2004).
} 
this has implications for many aspects of the democratic process, the core insight relevant to this paper is simply that public resources are placed at the disposal of local patrons. How these resources are then spent is at the discretion of these unelected patrons, who not only decide what goods and services are to be provided but also who benefits from public provision. ${ }^{30}$ The end result is that poor constituents lose out from the triadic clientelist network, as they lack the bargaining power to negotiate better terms for themselves. ${ }^{31}$

\section{The Impact of Connectivity}

Basu argues that landlords enjoy exploitative powers when inequality is accompanied with peasants having limited outside options for satisfying their needs. ${ }^{32}$ In isolated villages, landlords have strict control over a multiplicity of services (see above). This results in markets getting interlinked, where disagreement with the patron in any single market (e.g. political) has consequences for other markets (e.g. credit, housing, employment). ${ }^{33}$ It is thus the interaction of inequality with isolation that enables patrons in isolated villages to use sticks - from employment termination, eviction, refusal of credit to social ostracizing - rather than carrots to influence clients’ behaviour. $^{34}$

\footnotetext{
${ }^{30}$ Gazdar 2000.

${ }^{31}$ Keefer 2007; Mason and Joshi 2008.

${ }^{32}$ Basu 1986

${ }^{33}$ See for example Bardhan 1980; Basu 1986; Bhaduri 1977. Markets are interlinked when equilibria in multiple markets are jointly determined. Economics literature shows how a monopolistic landlord, due to the multiplicity of services he has to offer, is able to interlink markets so that equilibrium in a single market is tied to equilibria in most, or all, other markets. This makes disagreement with the landlord in any market very costly, as it results in negative spillovers to other markets. See also Author 2012a.

${ }^{34}$ Author 2012a; Dasgupta 1993; Mason 1986.
} 
Using road networks to connect villages to the broader market should change this bargaining relationship by creating exit options for peasants. ${ }^{35}$ One such option is through new employment possibilities. ${ }^{36}$ These are important even if the client continues to work for the patron. For, although connectivity does not necessarily result in a major shift in the rural employment market, the underlying nature of the relationship is significantly altered as exit options takes away patrons' ability to use the threat of employment sanctions as a means of controlling clients. ${ }^{37}$

Secondly, increased accessibility can attract an influx of new actors wanting to take advantage of the opportunities in these villages. This includes new resource-rich individuals who are willing and able to provide peasants with an alternative to their current patron in one or more markets. Rouse, while looking at the effects of capitalism in rural Pakistan, finds that new market opportunities created new elites in the rural economy, some of whom challenged the authority of the local landlord by offering support to peasants who defied the landlord. ${ }^{38}$ Equally, opening up a village may provide peasants with up new credit possibilities, insurance possibilities, dispute resolution options, and so forth that previously were under the monopoly of the landlord.

Whereas patrons in isolated villages can ensure that clients are excluded from public funds provided by the government without losing their support, ${ }^{39}$ market access should increase the bargaining power of clients. This in turn allows them to demand more public services to be ${ }^{35}$ Scott (1972) observed how unused land in rural Philippines limited the power of landlords as it provided peasants with alternative options.

${ }^{36}$ While the benefits of connectivity are dependent on the opportunities available in the external market, it can be argued that they would always be better than those found in an isolated village dominated by a large landlord (Platteau 1995).

${ }^{37}$ Wingrod and Morin 1971. See also Author 2012a.

${ }^{38}$ Rouse1988.

${ }^{39}$ Cheema and Mohmand (2005) found that villagers in rural Punjab, Pakistan, who supported the incumbent, but were not part of a patronage network, were less likely to enjoy public provision, as the incumbent mayor channelled funds towards local landlords. 
brokered by their patron. ${ }^{40}$ While these benefits would extend to all clients, they would be felt most strongly by vulnerable households as they are most likely to exit from the clientelist network whenever the opportunity presents itself. Therefore, the patron would have a strong incentive to divert resources towards these vulnerable households so as to retain their clientelist support.

This then results in two testable hypotheses regarding the effects of connectivity on the politics of rural economies:

1. By providing peasants with exit options, connectivity should reduce peasants' dependence on the local patron and therefore enable them to demand increased public provision in exchange for their votes. This effect should be felt most strongly in highly unequal villages where a dominant patron is found.

2. Within the village the benefits of connectivity should be felt most strongly by peasants who are most vulnerable to exploitation when isolated.

Before continuing, it is worth highlighting that exit options are not the only way in which connectivity could increase the bargaining power of the rural poor. For instance, Bailey (1957) found that the opening up of a small Indian village led to the emergence of new patrons altogether, who offered fierce competition to existing patrons for peasants' support. Yet, this development took decades, whereas the data used in the analysis below was collected shortly after the introduction of the road networks. Therefore, the introduction of new patrons is not the focus of this study.

Another important effect of connectivity could be through raising awareness amongst peasants regarding their political rights and possibilities, which may result in greater demands for

${ }^{40}$ The local patron has limited ability to either capture new opportunities from connectivity or bar villagers from participating in them, as it would entail erecting a barrier on the road network so as to restrict traffic (and external traders) from coming to the village. The costs of doing this would often be extremely high. Alternatively, the patron could make use of violence to bar clients from participating in the newly available market opportunities. But besides having legal implications, this too is a costly option as it leads to a loss of loyalty in an environment where peasants are valuable, at the very least, for their political support (Scott 1972). 
public provision in exchange for their votes. ${ }^{41}$ While this is an important mechanism, the nature of information flows makes it difficult to establish causation. Therefore, awareness, rather than being the focus of the analysis below, is included as a control.

\section{Empirical Analysis}

\section{The case of Pakistan}

Rural Pakistan is a good case to test the above framework for a number of interconnected reasons. Firstly, it has in place extensive clientelist networks infiltrating almost every aspect of villagers' lives. ${ }^{42}$ Secondly, the country suffers from low levels of accountability and weak institutional structures, thus making it possible for politicians to appropriate public funds without having to face severe consequences. ${ }^{43}$ As Gazdar notes, public resources in Pakistan are often used "as a currency for the disbursement of patronage". ${ }^{44}$ Even local club goods, such as drains and paved streets, are often targeted towards individual households aligned with the local patron. ${ }^{45}$ Neighbouring households, not aligned with the patron, are routinely excluded from such goods. ${ }^{46}$ Although, such blatant targeting is highly inefficient, it allows us to analyse the effect of changing bargaining power on public provision within villages.

\footnotetext{
${ }^{41}$ Prat and Strömberg 2006.

${ }^{42}$ Ahmad 1977; Gazdar 2000; Rouse 1988.

${ }^{43}$ Keefer 2004.

${ }^{44}$ Gazdar 2000, 77.

${ }^{45}$ Cheema and Mohmand 2008, 2005.

${ }^{46}$ This is something I also observe in my data with regards to drains and paved streets. It appears that what households care about is state resources being spent on them and not so much the provision of a functioning good.
} 
Third, in 2001 the military government, in an effort to legitimise its rule, instituted local government reforms that devolved public funds and their spending decisions to the local level. ${ }^{47}$ This influx of public funds provided a good opportunity to analyse how resources are distributed in villages with varying levels of bargaining powers between brokers and their clients.

Finally, but crucially, Pakistan offers a natural experiment to study the role of connectivity. In 1998, the federal government constructed a motorway connecting two major cities; Lahore and Islamabad. Along the $365 \mathrm{~km}$ of this road there are multiple exits, each of which has a link road connecting the motorway to the nearest city/town. These link roads run past villages that were previously connected by dirt trails which restricted traffic and peasant mobility. Through its extensive network of link roads, the motorway has resulted in an increase in traffic and outsiders coming to these villages. While mobility allows peasants to explore employment options outside the village economy, increased traffic has also led to the creation of new jobs within the village in the form of roadside cafes, vehicle repair shops, general stores, etc.

The decision regarding the placement of the motorway was made by the federal government based on three main considerations - geography, connectivity and defence. ${ }^{48}$ Efforts were made to minimize the stretch that ran through geographical hazards, while still ensuring that the route was not very close to the old highway and passed through as many towns and villages as possible. Also, the road had to avoid a military bombing range which was situated between Lahore and Islamabad thus making certain routes unfeasible. Even though none of these factors were systematically related to specific village characteristics, there were rumours that the placement of the motorway was altered in order to connect the lands of large landlords. While I was unable to find evidence to confirm this, I identified areas where the motorway was not altered from the original plan. Among

\footnotetext{
${ }^{47}$ See Faguet and Shami (2015) for details regarding Pakistan’s local government system.

${ }^{48}$ Republic Engineering Corporation Limited 1988.
} 
these was Hafizabad district. ${ }^{49}$ Looking through newspaper archives from around 1998 I found that, while there were allegations raised against large landlords from various parts of the country trying to influence the placement of the road, none of them pertained to landlords from Hafizabad. This is not surprising when we consider that landlords in this district, while commanding considerable authority in their own villages, would be considered part of the lower middle class in urban settings. This was quite evident from the houses they lived in, the cars they drove, the schools they sent their children to and their own levels of education. Hence, they lacked the clout needed to influence the federal government's decision. ${ }^{50}$ Moreover, Hafizabad's political representative in government around 1998 belonged to the opposition - a party that had strongly opposed the construction of the motorway $^{51}$ - and therefore was unlikely to be able to negotiate any changes in its route or its link roads. As a result, the motorway was an exogenous shock to Hafizabad's village economies.

\section{Methodology}

The empirical study makes use of data collected from villages located at varying proximity to the motorway ${ }^{52}$ in Hafizabad district. ${ }^{53}$ Villages are within the same unit of local government, face the same government budget and, as they are in the same district, are represented by the same Mayor. This allows me to control for the effect of Pakistan's local government reforms: if

\footnotetext{
${ }^{49}$ This was also verified through a personal interview with Chaudary Altaf, who had been the Director General of the National Highways Authority.

${ }^{50}$ GKH 2005.

${ }^{51}$ The idea of the motorway was first proposed in the late 1980s by the Muslim League (ML) government. However, construction was delayed because the Pakistan People's Party (PPP) came into power which was strongly opposed to the project.

${ }^{52}$ Proximity to the road refers to distance from the link roads.

${ }^{53}$ For other studies using this survey, see author (2012a) and author (2012b).
} 
improvements were due to decentralization, then we should see relatively equal levels of provision across the villages, irrespective of levels of inequality or isolation. ${ }^{54}$

Within the district, eight villages were chosen with four having the motorway link road run through them and four being situated at a distance of eight to eleven kilometres from these linkroads. Bad infrastructure has meant that travelling to distant villages took between 40 and 90 minutes by car from the motorway exit. Moreover, interviews with households revealed that, for most peasants, the biggest hurdle to travelling was the limited availability of transport facilities. Often villagers had to wait up to an hour to get a ride to the nearby town or city and, once there, found it difficult to find a ride back. Therefore, unless households had their own transport they tended to avoid going into the nearby town or city. ${ }^{55}$ Villagers situated close to the motorway, on the other hand, are now very mobile as there has been a substantial increase in the number of transport facilities available to them. Most households now have to wait less than ten minutes to get a ride, thus enabling them to travel to nearby towns and cities to look for work outside of the agricultural sector - a sector that is controlled mostly by the landlord. ${ }^{56}$ Moreover, the increase in traffic has meant that households can generate an additional income by providing goods and services to passers-by. My surveyors and I experienced this first-hand as we were often approached, by someone or the other, trying to sell us goods ranging from food to toys to little crowns made out of flowers. By contrast, in isolated villages the only people approaching us were little children who were curious about the outsiders in their village.

\footnotetext{
${ }^{54}$ The benefits of decentralisation are disputed in the literature. Some scholars argue that bringing the politician closer to the population allows citizens to demand provision, whereas others argue that decentralization leads to an increase in elite capture at the grass-roots level. For an overview, see Faguet 2012.

${ }^{55}$ Key respondent 2.

${ }^{56}$ This is evident from the fact that $51 \%$ of households in connected villages felt that there had been an increase in employment opportunities outside the agricultural sector, while only $37 \%$ of households felt the same in isolated villages $(\mathrm{p}<0.01$; see discussion of survey data below).
} 
The data used in this paper comes from a household-level survey conducted in 2008. While it would have been optimal to compare provision levels pre- and post-connectivity, such data does not exist as data collection in the region has been fairly limited. This paper overcomes this disadvantage through its research design which compares outcomes in villages dominated by large landlords (landlord-dominated villages) to villages with relatively egalitarian distribution of land (peasant-based villages). ${ }^{57}$ Following Banerjee and Iyers’ study of West Bengal, the expectation is that 'monopolist' (or monopsonist; see below) patrons in landlord-dominated villages appropriate public resources without jeopardising their clients' political support, whereas the competition among patrons in peasant-based villages forces them to channel more public funds towards their clients. ${ }^{58}$ In other words, peasant-based villages are used as a control group against which outcomes in connected and isolated landlord-dominated villages are compared. In addition, the paper relies on households' recall of provision levels prior to the construction of the motorway, which was verified through key respondent interviews. ${ }^{59}$

The village selection process involved identifying land holding patterns across the district. A village was classified as being landlord-dominated if any single household’s landholding was 100 acres or greater ${ }^{60}$ and there were a maximum of three households in the village with such large landholdings. The latter criterion was based on Platteau's (1995) finding that landlords in South Asia often abide by time honoured traditions of not accepting other landlords' run-away peasants. This enables patrons to act as monopolists/monopsonists even when they co-exist with one or two other large landlords in the village. Villages were also split based on their level of isolation, thereby

\footnotetext{
${ }^{57}$ Land distribution is exogenous to this model as it was historically determined by the British revenue collecting machinery (For more details see Nelson 2011).

${ }^{58}$ Banerjee and Iyer 2005.

${ }^{59}$ The motorway was a major shock to villages in the area and as a result households measured time from before and after the road. This makes recollection fairly reliable.

${ }^{60}$ This was the ceiling placed at the last land reforms carried out in Pakistan (Rashid 1985).
} 
creating 4 groups of villages; isolated landlord- and peasant-based villages and connected landlordand peasant-based villages. From this pool 2 villages were randomly selected from each group.

\begin{tabular}{l|c|c|} 
& \multicolumn{1}{c}{ Landlord-dominated } & Peasant-based \\
\cline { 2 - 3 } Close to the Motorway & 2 & 2 \\
\cline { 2 - 3 } & & 2 \\
\hline \multirow{2}{*}{ Far from the Motorway } & 2 & 2 \\
\cline { 2 - 3 } & &
\end{tabular}

In my sample, the land holdings of patrons in landlord-dominated villages vary from 100 to 300 acres. In peasant-based villages, on the other hand, the average landholding of patrons is only 23 acres. Incidence of landlessness amongst peasants is as high in peasant-based villages as in landlord-dominated villages. This similarity means that we expect the structure of clientelist networks to be relatively similar in peasant- and landlord-dominated villages. ${ }^{61}$ The difference, however, lies in the power that patrons enjoy within their respective clientelist networks. While the multiplicity of patrons means that no single landowner is powerful enough to wield control in peasant-based villages, the main landowner in landlord-dominated villages is large enough to be, for most peasants; the main source of employment, the owner of their homestead land and, most of the time, the main source of credit. This allows him to enjoy considerable control, which can be used to make high demands off the peasants.

Apart from these differences, the eight villages are relatively very similar. From Table 1 we find that while close to $70 \%$ of households derive their primary source of income from agriculture, around 54\% of households are landless. Therefore, a substantial portion of households working in the fields are dependent on local landlords for their livelihood.

\footnotetext{
${ }^{61}$ Recall from Section 1 that what drives peasants to join these networks is their inability to meet their basic needs themselves.
} 


\begin{tabular}{|c|c|c|c|c|}
\hline & $\begin{array}{l}\text { Villages } \\
\text { connected to } \\
\text { the road }\end{array}$ & $\begin{array}{l}\text { Villages far } \\
\text { from the } \\
\text { road }\end{array}$ & $\begin{array}{c}\text { Landlord } \\
\text { dominated } \\
\text { villages }\end{array}$ & $\begin{array}{c}\text { Peasant } \\
\text { based } \\
\text { villages }\end{array}$ \\
\hline Percentage households engaged in agriculture & $68 \%$ & $69 \%$ & $68 \%$ & $69 \%$ \\
\hline Percentage households who are landless & $51 \%$ & $54 \%$ & $53 \%$ & $54 \%$ \\
\hline Average household spending & $\$ 105$ & $\$ 100$ & $\$ 100$ & $\$ 103$ \\
\hline Percentage of households having three meals a day & $80 \%$ & $74 \%$ & $78 \%$ & $75 \%$ \\
\hline Average number of rooms in the house & 3 & 3 & 3 & 3 \\
\hline Average number of people in the house & 8 & 8 & 8 & 8 \\
\hline $\begin{array}{l}\text { Percentage of households headed by an illiterate } \\
\text { person }\end{array}$ & $50 \%$ & $48 \%$ & $54 \%$ & $45 \%$ \\
\hline $\begin{array}{l}\text { Percentage of households sending their children to } \\
\text { school }\end{array}$ & $78 \%$ & $75 \%$ & $77.4 \%$ & $75.3 \%$ \\
\hline Closest population welfare centre ${ }^{a}$ & $7 \mathrm{~km}$ & $5 \mathrm{~km}$ & $5 \mathrm{~km}$ & $7 \mathrm{~km}$ \\
\hline Closest police station ${ }^{2}$ & $9 \mathrm{~km}$ & $5 \mathrm{~km}$ & $9 \mathrm{~km}$ & $5 \mathrm{~km}$ \\
\hline $\begin{array}{l}\text { Percentage of households approaching the landlord for } \\
\text { dispute resolution }\end{array}$ & $61 \%$ & $59 \%$ & $59 \%$ & $67 \%$ \\
\hline Number of households & 190 & 193 & 182 & 201 \\
\hline
\end{tabular}

Author's own calculations, unless stated otherwise

a. Pakistan Census report 1998

Households’ average monthly spending was $\$ 100$ which sustains around 8 people living in a 3 room house, enabling around $76 \%$ of households to consume three meals a day. Furthermore, we can see that in all types of villages the state provides population welfare centres and police stations within a $10 \mathrm{~km}$ radius. However, around $60 \%$ of households choose to approach their patron for dispute resolution and claim to have always done so. However, through interviews, it became clear that most households' hesitation to use public institutions is not due to their distance, but rather due to their having little faith in government institutions. The only time they visit these institutions is when their patron accompanies them as his presence ensures that they will not be ignored.

The relative similarity between the villages enables us to make the counterfactual that, prior to the construction of the road, provision levels in these villages would not vary based on geography. This allows us to use the spatial variable (distance) as a proxy for time (before and after) with respect to the road. Combined with households' recall of provision levels prior to the 
construction of the motorway, this should give us a good indication of the effect connectivity has had on households’ chances of receiving public resources.

Within the eight villages, household-level surveys were collected from a stratified random sample of $20 \%$ of households. Stratification was done along biradery lines, as literature on South Asia documents this as being a good proxy for social status and is found to influence their relationship with the patron and thus the public resources that they enjoy. ${ }^{62}$ Within the selected villages, the upper class biraderies were the Kharrals and the Bhattis. These were historically the land owning classes, which gave them their elevated status. Interestingly, a Kharral or a Bhatti household is considered part of the upper class even if it is landless. Amongst the lower class particular emphasis was placed on Muslim Sheikhs and the Ansaris. These biraderies were historically not allowed to own land. Even though there is no legal restriction against them owning land today, almost all households of these biraderies were still landless in the villages. Muslim Sheikhs have the lower status among the two, as they are responsible for performing menial tasks which others consider demeaning (such as cleaning village drains).

The analysis is restricted to two publicly provided goods; drains and paved streets. The reason lies in the nature of these goods and the way in which they are provided in rural Pakistan. As mentioned earlier, drains and paved streets in rural Pakistan tend to be excludable goods. This holds true even within a neighbourhood, where one would intuitively expect such goods to be nonexcludable in order to be effective. Moreover, these goods tend to be provided through a local patron, who is responsible for deciding on their quantity, quality and placement.

The two goods are also useful to analyse jointly due to their impact on mobility. In the absence of a drain, households' waste flows directly onto the street outside their main doors. This, besides spreading diseases, makes it difficult for people to move around, particularly if the street is

${ }^{62}$ Ahmad 1977; Alavi 1972. 
not paved. ${ }^{63}$ Perhaps as a result, households in my survey were indifferent between getting drains or paved streets (although they would of course prefer both).

In order to test the effects of connectivity the following logistic regression models are run:

$\mathrm{Y}_{\mathrm{iv}}=\alpha+\beta_{1} \mathrm{MW}_{\mathrm{v}}+\beta_{2} L L_{\mathrm{v}}+\beta_{3} \mathrm{Land}_{\mathrm{iv}}+\beta_{4} \mathrm{Bh}_{\mathrm{iv}}+\beta_{5} \cdot \mathrm{Kh}_{\mathrm{iv}}+\beta_{6} \mathrm{An}_{\mathrm{iv}}+\beta_{7} \mathrm{MS}_{\mathrm{iv}}+\xi_{\mathrm{iv}}$

$\mathrm{Y}_{\mathrm{iv}}=\alpha+\beta_{1} \mathrm{MW}_{\mathrm{v}}+\beta_{2} \mathrm{LL}_{\mathrm{v}}+\beta_{3} \mathrm{MW}_{\mathrm{v}}{ }_{\mathrm{L}} \mathrm{L}_{\mathrm{v}}+\beta_{4} \mathrm{Land}_{\mathrm{iv}}+\beta_{5} \mathrm{Bh}_{\mathrm{iv}}+\beta_{6} \mathrm{Kh}_{\mathrm{iv}}+\beta_{7} \mathrm{An}_{\mathrm{iv}}+\beta_{8} \mathrm{MS}_{\mathrm{iv}}+\xi_{\mathrm{iv}}$

$\mathrm{Y}_{\mathrm{iv}}$ is a binary variable taking the value of 1 if household $i$ in village $v$ has received state provision, 0 otherwise. Distance from the road, $\mathrm{MW}_{\mathrm{v}}$, takes the value of 1 if the household resides in an isolated village, and 0 otherwise. Distance is a binary rather than continuous variable as the research design looks at villages which were polar opposite, i.e. while half have the motorway link road running through the village, the other half are far enough to be classified as being isolated. Within this setup modest changes in distance are irrelevant in practise. Distance is used as a proxy for exit options as it helps capture both realised opportunities and potential ones. These can then be used by the client as a credible threat to negotiate better terms. $L L_{v}$ is 1 if the household resides in a village dominated by a large landlord, and 0 if it is in a peasant-based village. Land iv $_{\text {is a continuous }}$ variable, measured in acres, capturing the amount of land owned by peasant households. This variable is included because land owning households have higher bargaining power vis-à-vis the landlord as they are less dependent on him than landless households. ${ }^{64}$ The last four variables are dummies for the major biraderies found in the villages which are included as a control for the social status of the household. $\mathrm{Bh}_{\mathrm{iv}}$ and $\mathrm{Kh}_{\mathrm{iv}}$ take the value of 1 if the household belongs to the Bhatti or Kharral biradery respectively. $\mathrm{An}_{\mathrm{iv}}$ is 1 if the household is an Ansari and $\mathrm{MS}_{\mathrm{iv}}$ is 1 if the household's biradery is Muslim Sheikh. The variable $M W_{v}{ }^{*} L_{v}$ in Equation 2 is an interaction term which captures the effect of belonging to a landlord-dominated village far from the road.

Connectivity is also expected to have spillover effects on a household's level of awareness. It could be argued then that the impact of the motorway on public provision levels is not through an

\footnotetext{
${ }^{63}$ I would like to thank Hadia Majid for bringing this point to my attention.

${ }^{64}$ Scott 1972.
} 
increase in peasants' bargaining power - the focus of this paper - but rather due to an increase in levels of awareness. Hence it is possible that Equations 1 and 2 suffer from an omitted variable bias and are over-estimating the effect of the road through exit options. Therefore, as robustness checks the basic model is adjusted to include controls for levels of awareness:

$\mathrm{Y}_{\mathrm{iv}}=\alpha+\beta_{1} \mathrm{MW}_{\mathrm{v}}+\beta_{2} \mathrm{LL}_{\mathrm{v}}+\beta_{3} \mathrm{MW}_{\mathrm{v}}{ }^{*} \mathrm{LL}_{\mathrm{v}}+\beta_{4} \mathrm{Land}_{\mathrm{iv}}+\beta_{5} \mathrm{~N}_{\mathrm{iv}}+\beta_{6} \mathrm{H}_{\mathrm{iv}}+\beta_{7} \mathrm{Bh}_{\mathrm{iv}}+\beta_{8} \mathrm{Kh}_{\mathrm{iv}}+\beta_{9} \mathrm{An}_{\mathrm{iv}}+$ $\beta_{10} \mathrm{MS}_{\mathrm{iv}}+\xi_{\mathrm{iv}}$

Awareness is measured through two proxies; whether the household has access to a newspaper ${ }^{65}\left(\mathrm{~N}_{\mathrm{iv}}\right)$ and whether the household has heard about local government participatory bodies $\left(\mathrm{H}_{\mathrm{iv}}\right){ }^{66}$ The local government ordinance in Pakistan has made provision for four participatory bodies that are meant to facilitate participatory development and increase political accountability. However, their functionality has been limited, ironically due to citizens being unaware of their existence. ${ }^{67}$ While connectivity would have an impact on these variables, as mentioned above, the nature of information flow makes it very difficult to determine the cause of the increase.

Lastly, following from hypothesis 2, the paper investigates the effect of connectivity on vulnerable households. Household vulnerability is measured through two variables; households' social status and the extent of their interaction with the landlord. As mentioned before, multiple dealings with the landlord can result in transactions being interlinked so that equilibria for a bundle of transactions are jointly determined. Aside from the efficiency implications, such transactions tend to have severe welfare implications for economically and socially poor households, as a disagreement in one market has consequences for all other dealings with the landlord. Therefore,

\footnotetext{
${ }^{65}$ Access simply means they are able to get information irrespective of whether they subscribe to a newspaper themselves, are reading it at a nearby shop or friend's house, or are having a friend relay information to them.

${ }^{66}$ The correlation between connectivity and having heard about participatory bodies is -0.07 while the correlation between connectivity and access to a newspaper is 0.03 .

${ }^{67}$ Kurosaki 2007.
} 
households in an interlinked relationship should be less inclined to withdraw their political support from a landlord who does not broker public resources for them. This is tested with the following specification:

$\mathrm{Y}_{\mathrm{iv}}=\alpha+\beta_{1} \mathrm{MW}_{\mathrm{v}}+\beta_{2} \mathrm{LL}_{\mathrm{v}}+\beta_{3} \mathrm{MW}_{\mathrm{v}} * \mathrm{LL}_{\mathrm{v}}+\beta_{4} \operatorname{Inter}_{\mathrm{iv}}+\beta_{5} \mathrm{MW}_{\mathrm{v}}{ }^{*} \operatorname{Inter}_{\mathrm{iv}}+\beta_{6} \mathrm{Land}_{\mathrm{iv}}+\beta_{7} \mathrm{Bh}_{\mathrm{iv}}+\beta_{8} \mathrm{Kh}_{\mathrm{iv}}$

$+\beta_{9} \mathrm{An}_{\mathrm{iv}}+\beta_{10} \mathrm{MS}_{\mathrm{iv}}+\xi_{\text {iv }}$

Inter $_{\text {iv }}$ takes the value of 1 if the household has multiple dealings with the landlord. For instance, a household is said to be in an interlinked relationship if its members work for the landlord and approach him for credit and dispute resolution. $\mathrm{MW}_{\mathrm{v}} *$ Inter $_{\text {iv }}$ tests the effect of isolation on households engaged in this market structure. The remaining variables are the same as in the equations above.

\section{Empirical Results}

Figure 1 looks at provision levels pre-motorway, based on household recall. As can be seen, provision levels are fairly similar irrespective of the village's location. The small difference is not statistically significant. ${ }^{68}$ This means that in the absence of purely political considerations (like links with local patrons), politicians have no inherent reason to target some villages over others as no-one was relatively disadvantaged.

${ }^{68}$ Significance is calculated using the Chi-square test. 


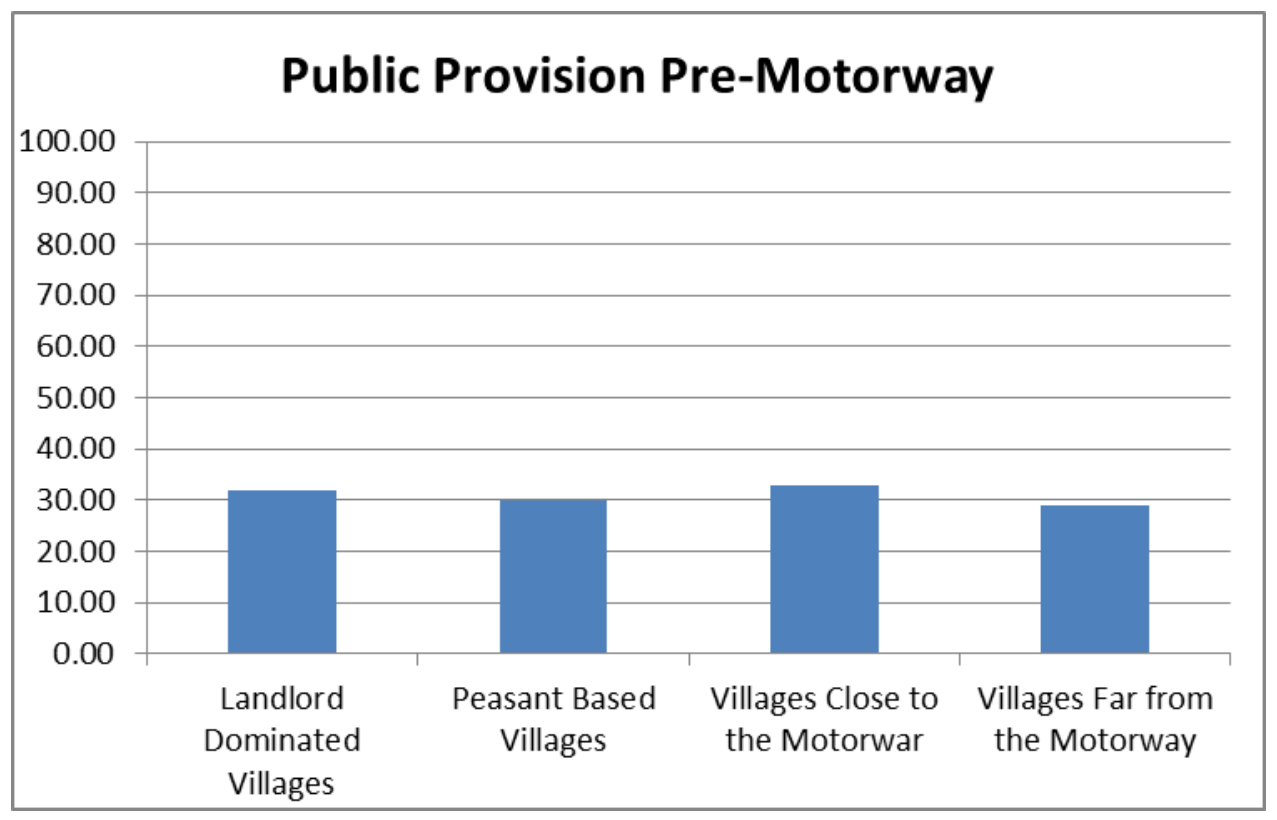

This similarity holds even after controlling for household and village characteristics. Table 2 runs a logistic regression model in order to establish that the road is in fact an exogenous shock with respect to public provision. As can be seen, the variable for connectivity is insignificant. This, therefore, allows us to rule out the possibility that there are systematic differences in terms of public provision based on the location of the villages. Interestingly, the variable for land tenure systems is also insignificant. Figure 1 above highlights how provision levels are very similar in both landlorddominated and peasant-based villages. This is contrary to our expectation, as theory would predict provision levels to be higher in peasant-based villages than in landlord-dominated ones. One possible explanation could lie in the undefined age of the good provided by the government. While households could recall whether the drain or street was provided before or after the motorway, they were typically unable to recall how old it was. This means that provision pre-motorway could be anywhere between 10 to 30 to even 40 years old. Therefore, cumulatively provision levels between the two villages seem to have converged. 
Table 2: Does the household benefit from state provision?

\begin{tabular}{lcc}
\hline Public provision & 1 & 2 \\
\hline Mousehold is situated far from the & $\begin{array}{c}\text { Pre- } \\
\text { Motorway }\end{array}$ & $\begin{array}{c}\text { Pre- } \\
\text { Motorway }\end{array}$ \\
motorway & $(0.03$ & 0.03 \\
Household belongs to a landlord- & 0.01 & $(0.46)$ \\
dominated village & $(0.83)$ & 0.06 \\
Household belongs to a landlord- & & $(0.40)$ \\
dominated village far from the & & -0.11 \\
motorway & & $(0.23)$ \\
Amount of land owned by the & $0.003 * *$ & $0.003 * *$ \\
household (acres) & $(0.02)$ & $(0.05)$ \\
& & -0.004 \\
household has access to a & & $(0.39)$ \\
newspaper & & -0.02 \\
Bhatti & -0.001 & $(0.47)$ \\
& $(0.98)$ & 0.1 \\
Kharral & 0.08 & $(0.27)$ \\
Ansari & $(0.32)$ & 0.11 \\
Muslim Sheikh & 0.11 & $(0.38)$ \\
& $(0.39)$ & -0.8 \\
Noudo & & $(0.34)$ \\
\hline
\end{tabular}

However, this does not mean that villagers on the whole are unaffected by land tenure systems. Figure 2 goes on to analyse how total spending is divided between the different social classes in these villages. We find that while the majority of public funds are directed towards the upper class in landlord-dominated villages (the difference is significant at the $1 \%$ level), in peasantbased villages the distribution is more equal between the social classes. Table A1, illustrates that these differences hold even after controlling for geography and awareness levels. This is in line with the expectation that upper class households have stronger bargaining power vis-à-vis the landlord, even in landlord-dominated villages, and therefore are able to secure public provision for themselves. The lower classes, who are extremely vulnerable and thus suffer from weak bargaining 
power, receive only $17 \%$ of the total goods provided to these villages. Such discrimination is not evident in peasant-based villages. ${ }^{69}$

Figure 2:Distribution of Public Resources Between Social Classes Pre-Motorway

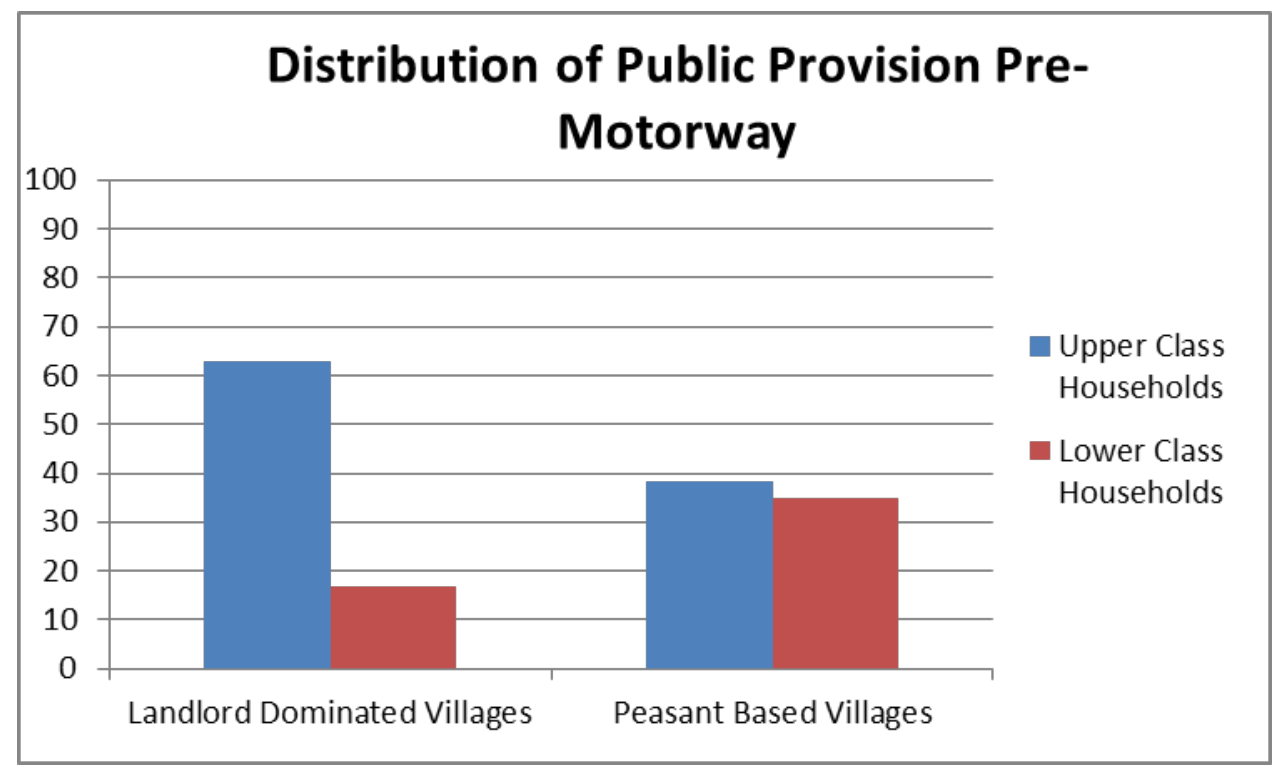

Figure 3 illustrates the total level of public provision across the different types of villages at the time of the survey. ${ }^{70}$ As a start, we can see that households situated in isolated landlorddominated villages have the lowest levels of public provision when compared to all other types of villages. However, this disadvantage is clearly not due to isolation as households residing in equally isolated peasant-based villages enjoyed significantly higher levels of state provision. This difference is significant at the $1 \%$ level. Multiplicity of patrons in peasant-based villages has meant that, even when isolated, no single patron is strong enough to demand his clients' political support without securing public resources for them.

\footnotetext{
${ }^{69}$ The small difference between the two is not statistically significant.

${ }^{70}$ This is both after the construction of the motorway and local government reforms, which transferred funds to the local level.
} 


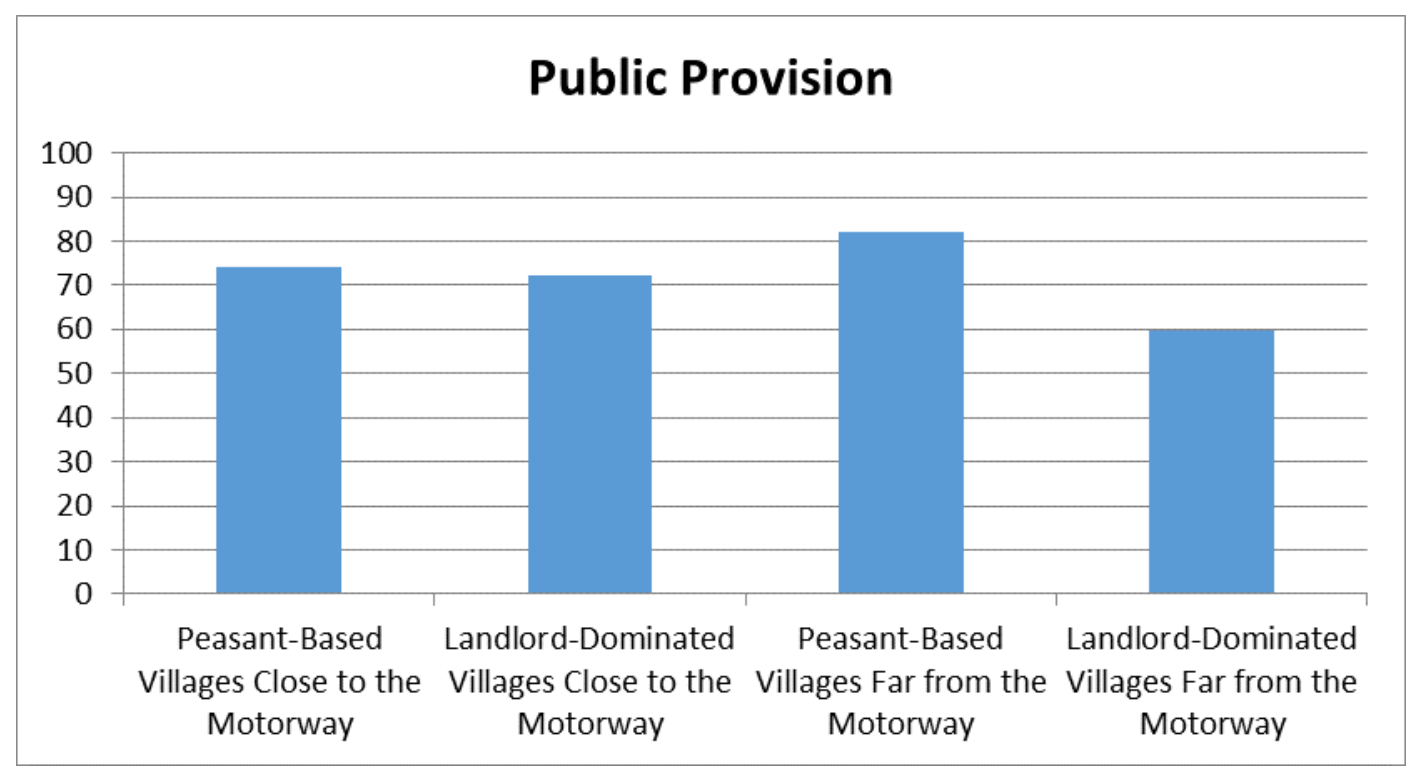

Turning to landlord-dominated villages we find that public provision is substantially higher in connected landlord-dominated villages when compared to isolated ones. This difference is significant at the $10 \%$ level. In fact, the figure reveals that provision levels in landlord-dominated villages, close to the road, are converging towards those found in peasant-based villages. This lends support to the argument that inequality by itself too is not sufficient to afford landlords monopolistic control over their clients. When comparing connected and isolated peasant-based villages, the difference in provision levels is insignificant. ${ }^{71}$

Before continuing, it is worth commenting on the curious finding that provision levels are highest in isolated peasant-based villages. This can be explained by the fact that patrons in these villages spend more on drains, which are cheaper to provide, than on paving streets which are more expensive (see figure $1 \mathrm{~A}$ in the appendix). In peasant-based villages close to the road, public resources were split between the cheaper drains and (more expensive) paved streets. This resulted in slightly fewer households benefiting from state provision (the small difference is statistically insignificant). Since households expressed an equal preference between drains and paved streets,

\footnotetext{
${ }^{71}$ High provision levels in isolated peasant-based villages rule out the possibility that politicians were targeting visible villages to demonstrate their responsiveness to their wider constituency. See Shami and Majid (2014) for a discussion on the impact of visibility on politicians’ spending decisions.
} 
service providers used their discretion in deciding how funds were spent between these two types of goods. Therefore, the difference observed was merely a reflection of the choices brokers made.

The findings above resonate with the information that peasants and landlords provided during qualitative interviews. Talking to one landlord in a connected village it was clear that, in the absence of economic sanctions he lacked the ability to coerce peasants' political decisions and therefore, had to provide positive incentives instead. This was evident from his description of the effect of the motorway:

“Things are very different since the construction of the motorway. Previously all I had to do was express a need and peasants used to come running to help. Now it is different. Now the peasants prefer to pursue the new alternatives made available by the motorway. As a result, I can no longer expect them to do whatever I say, rather I have to give them something in return."72

Peasants too seemed mindful of this change; "Now (after the construction of the motorway) he has to tend to our needs as he needs us to work in his fields"73, was the response of one household regarding why their landlord channelled public funds to them. Most households were not only aware, but were also fairly vocal, about the fact that connectivity had increased exit options which they could exercise if the exchange with the landlord was not beneficial. And since markets in these villages were interlinked, the calculation regarding whether the exchange with the landlord was beneficial took political provision into account. Therefore, in order to retain his labourers, the landlord now had to take their political needs into account. However, this is not to say that these

\footnotetext{
${ }^{72}$ Landlord 1 . This change was felt so acutely by the landlord that not only was he found to broker public funds, he also encouraged peasants to collectively self provide for goods. He did this by providing financial and moral support for such activities. See Author 2012b for details.

${ }^{73}$ Household ID 266.
} 
landlords don't also have political motives for brokering public funds. When probed as to why there had been an increase in public provision in the village over the last few years, one large landlord from a connected village responded: "During elections they are more likely to align with me politically if I help provide them with the goods and services they need." 74

Households too were aware of their newfound political power as, in response to the same question, one household replied: "He helps us because he wants our political support"75. This sentiment was expressed by many in connected villages, particularly by younger members of the households. Such political assuredness was in stark contrast to the attitude of villagers in isolated landlord-dominated villages. The autarkic nature of the economy meant that the large landlord had a strong hold on most economic opportunities in the village economy and could bar non-complying households from access to these resources. Peasant households, on their part, had no doubt that he would cut them off for disobeying him. As one household told me: "where would we go if we defied him?"76 Another stated: "How would we feed our children if he cuts us off?" ${ }^{77}$ While drains and paved streets were certainly important to these households, they were a small price to pay to have access to resources that helped maintain their subsistence. ${ }^{78}$

Being aware of this, the patrons from isolated landlord-dominated villages had no qualms about diverting public funds towards their own neighbourhoods. As a result, the area around their houses had well paved streets and functioning drains, while most of the village sat in disrepair. The patrons from the connected villages enjoyed no such luxury. As one of them pointed out: “Look

\footnotetext{
${ }^{74}$ Landlord 1, cited in Author (2012b).

${ }^{75}$ Household ID 258.

${ }^{76}$ Household ID 45, cited in Author (2012a).

${ }^{77}$ Household ID 286, cited in Author (2012a).

${ }^{78}$ In these villages households questioned whether voting independently would result in politicians being more responsive to their needs. Thus, while aligning with the broker didn’t wield public provision, it did guarantee subsistence.
} 
outside my house, my own street is unpaved. I dare not fix it as otherwise peasants will come and shout at me for not fixing their streets also."79

So while peasants in connected villages seemed to be putting considerable stock into their patron's ability to secure funds for them and thus based their voting decision on it, those in isolated landlord-dominated villages clearly did not, as blatant elite capture in their villages had limited impact on their decision to align politically with their patron.

The tables that follow run logistic regressions to test whether the findings above hold after controlling for village and household level characteristics. The analysis is carried out in three steps. Table 3 starts by looking at the aggregate data. It focuses mainly on connectivity and land tenure systems while controlling for household level characteristics. Step 2 looks at who within the village is benefitting from connectivity by disaggregating the data (see Table 4). This is done on the expectation that large variation in household level variables in the different villages would cause their impact to be averaged out in the aggregate data. Lastly, Table 5 takes a closer look at vulnerable households - measured through the presence of interlinked relationships - using both aggregate data and a sample restricted to landlord-dominated villages.

Starting with the basic model, Table 3 shows, similar to Banerjee’s and Iyer’s argument, that land tenure system matters for public provision. ${ }^{80}$ Those situated in landlord-dominated villages are $13 \%$ less likely to enjoy state provision when compared to households in peasant-based villages. However, the introduction of the interaction term in Column 2 reveals that this disadvantage holds only when villages are isolated from the external economy. In line with hypothesis 1, peasants residing in isolated landlord-dominated villages are $18 \%$ (see Table 3.a.) ${ }^{81}$ less likely to have state provision directed towards them when compared to households in connected peasant-based villages.

\footnotetext{
${ }^{79}$ Landlord 1.

${ }^{80}$ Banerjee and Iyer 2005.

${ }^{81}$ The full effect of the interaction term cannot be read straight from the table. It is calculated by adding together the interaction term and the coefficient of the two variables when not interacted.
} 
Column 3 runs the extended model to check whether the effect of connectivity holds after controlling for levels of awareness. As can be seen the interaction term continues to be significant.

Table 3.a displays partial effects which allows us to look at the effect of connectivity separately on landlord-dominated and peasant-based villages and the effect of inequality separately on isolated and connected villages. Starting with the effects of connectivity, the first row illustrates the benefits accrued to landlord-dominated villages. We find that households residing in isolated landlord-dominated villages are $17 \%$ less likely to enjoy public provision when compared to those in connected landlord-dominated villages. Peasant-based villages, however, don't seem to be affected by connectivity as the second row shows the effect of the road to be insignificant. Turning next to the effect of inequality, from Column 2 we can see that households residing in isolated landlord-dominated villages are $24 \%$ less likely to enjoy state provision when compared to those living in just as isolated peasant-based villages. Connectivity seems to eradicate this disadvantage as the difference in outcomes amongst the two types of villages is insignificant (see Column 1). 
Table 3: Does the household benefit from state provision?

\begin{tabular}{|c|c|c|c|}
\hline Public provision & 1 & 2 & 3 \\
\hline & $\begin{array}{l}\text { Post- } \\
\text { Motorway }\end{array}$ & $\begin{array}{l}\text { Post- } \\
\text { Motorway }\end{array}$ & $\begin{array}{c}\text { Post- } \\
\text { Motorway }\end{array}$ \\
\hline $\begin{array}{l}\text { Household is situated far from the } \\
\text { motorway }\end{array}$ & $\begin{array}{l}-0.06 \\
(0.3)\end{array}$ & $\begin{array}{l}0.06 \\
(0.4)\end{array}$ & $\begin{array}{c}0.06 \\
(0.42)\end{array}$ \\
\hline $\begin{array}{l}\text { Household belongs to a landlord- } \\
\text { dominated village }\end{array}$ & $\begin{array}{l}-0.13 * * \\
(0.02)\end{array}$ & $\begin{array}{l}-0.01 \\
(0.85)\end{array}$ & $\begin{array}{l}-0.01 \\
(0.82)\end{array}$ \\
\hline $\begin{array}{l}\text { Household belongs to a landlord- } \\
\text { dominated village far from the } \\
\text { motorway }\end{array}$ & & $\begin{array}{l}-0.23 * * * \\
(0.00)\end{array}$ & $\begin{array}{c}-0.23 * * * \\
(0.00)\end{array}$ \\
\hline $\begin{array}{l}\text { Amount of land owned by the } \\
\text { household (acres) }\end{array}$ & $\begin{array}{l}0.001 \\
(0.5)\end{array}$ & $\begin{array}{c}0.00 \\
(0.62)\end{array}$ & $\begin{array}{c}0.00 \\
(0.63)\end{array}$ \\
\hline $\begin{array}{l}\text { Household has access to a } \\
\text { newspaper }\end{array}$ & & & $\begin{array}{c}0.02 \\
(0.81)\end{array}$ \\
\hline $\begin{array}{l}\text { Household has heard of } \\
\text { participatory bodies }\end{array}$ & & & $\begin{array}{l}-0.002 \\
(0.43)\end{array}$ \\
\hline Bhatti & $\begin{array}{l}-0.03 \\
(0.77)\end{array}$ & $\begin{array}{l}-0.07 \\
(0.40)\end{array}$ & $\begin{array}{l}-0.07 \\
(0.38)\end{array}$ \\
\hline Kharral & $\begin{array}{l}-0.09 * \\
(0.06)\end{array}$ & $\begin{array}{l}-0.04 \\
(0.35)\end{array}$ & $\begin{array}{l}-0.04 \\
(0.25)\end{array}$ \\
\hline Ansari & $\begin{array}{l}-0.15^{* *} \\
(0.05)\end{array}$ & $\begin{array}{l}-0.15^{*} \\
(0.06)\end{array}$ & $\begin{array}{l}-0.15^{*} \\
(0.06)\end{array}$ \\
\hline Muslim Sheikh & $\begin{array}{l}-0.12 \\
(0.17)\end{array}$ & $\begin{array}{l}-0.11 \\
(0.24)\end{array}$ & $\begin{array}{l}-0.11 \\
(0.24)\end{array}$ \\
\hline $\mathrm{N}$ & 383 & 383 & 383 \\
\hline Pseudo $\mathrm{R}^{2}$ & 0.039 & 0.054 & 0.055 \\
\hline
\end{tabular}

Robust standard errors, clustered by villages, calculated. P-values in parentheses $* * * \mathrm{p}<0.01,{ }^{* *} \mathrm{p}<0.05, * \mathrm{p}<0.1$

Table 3.a. Partial effects of connectivity and land tenure system on provision levels

\begin{tabular}{|l|c|c|c|}
\hline \multirow{2}{*}{ Public provision } & $\begin{array}{c}\text { Connected } \\
\text { Villages } \\
(1)\end{array}$ & $\begin{array}{c}\text { Isolated Villages } \\
(2)\end{array}$ & $\begin{array}{c}\text { Effect of } \\
\text { Connectivity } \\
\text { Landlord-dominated villages }\end{array}$ \\
\cline { 2 - 4 }
\end{tabular}


Another interesting finding in Table 3 is the lack of significance of the landholding variable. While prior to the construction of the motorway provision was directed towards landed households (see Table 2), post-motorway they don't seem to enjoy any significant advantage. This lends support to hypothesis 2 that the benefits of connectivity are extending to the poorer members of the village economy. In order to explore this further and get a better understanding of who within the village is benefiting from connectivity, Table 4 splits the data by distance and levels of inequality.

\section{Who benefits from connectivity?}

To start with, table 4 reaffirms the findings above. Connectivity has a beneficial impact on landlord-dominated villages (see columns 1 and 2) while multiplicity of patrons has a beneficial impact on isolated villages (see columns 3 and 4).

Turning to household level variables, we find that land ownership continues to matter for provision in isolated villages but has no significant impact in connected ones. This lends support to the argument that, increase in outside options has a similar effect on a household's chances of benefitting from state resources as land ownership i.e. it provides them with alternative options for earning a livelihood which, in turn, reduces their dependence on the patron. As a result, villagers should be in a stronger position to demand public provision in return for their votes.

Looking at the effect of social class, we can see that while Muslim Sheikh households living in remote villages have a $21 \%$ lower chance of receiving publicly provided goods than the middle class, in isolated village none of the Ansari households have received any provision through the state. Once connected to the external economy though, both Ansaris and Muslim Sheiks face no significant disadvantage. The advantage to the socially lower classes seems to be at the expense of the upper classes, as Bhatti households in connected villages are $20 \%$ less likely to benefit from state provision. From Column 1 we can see that the disadvantage to Bhatti households is mainly in landlord-dominated villages. A curious finding is that Kharral households, who also belong to the upper class, have a 14\% lower chance of receiving public resources when isolated. However, 
looking at the results in Column 2 it can be seen that this is driven by outcomes in peasant-based villages.

Table 4: Does the household benefit from state provision?

\begin{tabular}{|c|c|c|c|c|}
\hline & \multicolumn{4}{|c|}{ Provision post 1998} \\
\hline & 1 & 2 & 3 & 4 \\
\hline & $\begin{array}{c}\text { Landlord } \\
\text { dominated } \\
\text { villages }\end{array}$ & $\begin{array}{c}\text { Peasant } \\
\text { based } \\
\text { villages }\end{array}$ & $\begin{array}{c}\text { Close to } \\
\text { the } \\
\text { motorway }\end{array}$ & $\begin{array}{c}\text { Far from } \\
\text { the } \\
\text { motorway }\end{array}$ \\
\hline Household is situated far from the motorway & $\begin{array}{c}-0.19 * * * \\
(0.00)\end{array}$ & $\begin{array}{r}-0.005 \\
(0.99)\end{array}$ & & \\
\hline $\begin{array}{l}\text { Household belongs to a landlord-dominated } \\
\text { village }\end{array}$ & & & $\begin{array}{c}0.02 \\
(0.60)\end{array}$ & $\begin{array}{c}-0.19 * * \\
(0.05)\end{array}$ \\
\hline Amount of land owned by the household (acres) & $\begin{array}{l}-0.00 \\
(0.67)\end{array}$ & $\begin{array}{l}0.003 \\
(0.14)\end{array}$ & $\begin{array}{l}-0.000 \\
(0.89)\end{array}$ & $\begin{array}{l}0.001 * \\
(0.09)\end{array}$ \\
\hline Household has heard of participatory bodies & $\begin{array}{c}0.07 \\
(0.57)\end{array}$ & $\begin{array}{l}-0.01 \\
(0.87)\end{array}$ & $\begin{array}{c}0.04 \\
(0.79)\end{array}$ & $\begin{array}{c}0.01 \\
(0.91)\end{array}$ \\
\hline Household has access to a newspaper & $\begin{array}{c}-0.002 \\
(0.4)\end{array}$ & $\begin{array}{c}0.04 \\
(0.14)\end{array}$ & $\begin{array}{c}0.09 \\
(0.15)\end{array}$ & $\begin{array}{c}-0.01^{* * * *} \\
(0.00)\end{array}$ \\
\hline Bhatti & $\begin{array}{c}-0.16 * * * \\
(0.00)\end{array}$ & $\begin{array}{l}-0.02 \\
(0.88)\end{array}$ & $\begin{array}{l}-0.2^{* *} \\
(0.02)\end{array}$ & $\begin{array}{l}-0.02 \\
(0.7)\end{array}$ \\
\hline Kharral & $\begin{array}{l}-0.05 \\
(0.41)\end{array}$ & $\begin{array}{c}-0.11^{* * *} \\
(0.00)\end{array}$ & $\begin{array}{c}-0.03 \\
(0.67)\end{array}$ & $\begin{array}{c}-0.14 * * * \\
(0.01)\end{array}$ \\
\hline Ansari & $\begin{array}{l}-0.06 \\
(0.48)\end{array}$ & $\begin{array}{l}-0.21 * \\
(0.07)\end{array}$ & $\begin{array}{c}0.03 \\
(0.76)\end{array}$ & \\
\hline Muslim Sheikh & $\begin{array}{l}-0.14^{*} \\
(0.08) \\
\end{array}$ & $\begin{array}{l}-0.05 \\
(0.72) \\
\end{array}$ & $\begin{array}{l}-0.03 \\
(0.82) \\
\end{array}$ & $\begin{array}{c}-0.21^{* * *} \\
(0.00)\end{array}$ \\
\hline $\mathrm{N}$ & 182 & 201 & 190 & 177 \\
\hline Pseudo $\mathrm{R}^{2}$ & 0.0917 & 0.0282 & 0.0224 & 0.1203 \\
\hline
\end{tabular}

Overall Table 4 presents strong evidence in support of hypothesis 2; Connectivity seems to be reducing the disadvantage that poor and socially disadvantaged households felt when isolated from the external market. Table 5 goes a step further, by including a measure for household vulnerability (the presence of interlinked relationships), to gauge whether the benefits of connectivity extend to the truly vulnerable households. 
Table 5: Does the household benefit from state provision?

\begin{tabular}{|c|c|c|}
\hline Public provision & 1 & 2 \\
\hline & $\begin{array}{c}\text { Full } \\
\text { Sample }\end{array}$ & $\begin{array}{c}\text { Landlord- } \\
\text { Dominated } \\
\text { Villages }\end{array}$ \\
\hline \multirow[t]{2}{*}{ Household is situated far from the motorway } & 0.11 & -0.12 \\
\hline & $(0.16)$ & $(0.20)$ \\
\hline \multirow[t]{2}{*}{ Household belongs to a landlord-dominated village } & -0.01 & \\
\hline & $(0.83)$ & \\
\hline \multirow{2}{*}{$\begin{array}{l}\text { Household belongs to a landlord-dominated village } \\
\text { far from the motorway }\end{array}$} & $-0.23 * * *$ & \\
\hline & $(0.00)$ & \\
\hline \multirow[t]{2}{*}{ Household is engaged in an interlinked relationship } & -0.03 & $0.08 * *$ \\
\hline & $(0.65)$ & $(0.02)$ \\
\hline \multirow{2}{*}{$\begin{array}{l}\text { Household resides in an isolated village and is } \\
\text { engaged in an interlinked relationship }\end{array}$} & -0.09 & -0.14 \\
\hline & $(0.25)$ & $(0.19)$ \\
\hline \multirow[t]{2}{*}{ Amount of land owned by the household (acres) } & 0.00 & 0.00 \\
\hline & $(0.82)$ & $(0.65)$ \\
\hline \multirow[t]{2}{*}{ Household has access to a newspaper } & -0.00 & -0.00 \\
\hline & $(0.57)$ & $(0.50)$ \\
\hline \multirow[t]{2}{*}{ Household has heard of participatory bodies } & 0.02 & 0.08 \\
\hline & $(0.79)$ & $(0.50)$ \\
\hline \multirow[t]{2}{*}{ Bhatti } & -0.09 & $-0.15^{* * *}$ \\
\hline & $(0.25)$ & $(0.00)$ \\
\hline \multirow[t]{2}{*}{ Kharral } & -0.05 & -0.04 \\
\hline & $(0.22)$ & $(0.42)$ \\
\hline \multirow[t]{2}{*}{ Ansari } & $-0.16^{* *}$ & -0.07 \\
\hline & $(0.05)$ & $(0.44)$ \\
\hline \multirow[t]{2}{*}{ Muslim Sheikh } & -0.09 & $-0.14 * *$ \\
\hline & $(0.29)$ & $(0.04)$ \\
\hline $\mathrm{N}$ & 383 & 182 \\
\hline Pseudo $\mathrm{R}^{2}$ & 0.0623 & 0.102 \\
\hline
\end{tabular}

Robust standard errors, clustered by villages calculated. P-values in parentheses ${ }^{* * *} \mathrm{p}<0.01,{ }^{* *} \mathrm{p}<0.05,{ }^{*} \mathrm{p}<0.1$

Table 5.a. Partial effects of connectivity and interlinked relationships on public provision (Landlord-dominated villages only)

\begin{tabular}{|l|c|c|c|}
\hline \multirow{2}{*}{ Public Provision } & $\begin{array}{c}\text { Connected Villages } \\
(1)\end{array}$ & $\begin{array}{c}\text { Isolated Villages } \\
(2)\end{array}$ & $\begin{array}{c}\text { Effect } \\
\text { Connectivity } \\
(3)\end{array}$ \\
\hline \multirow{2}{*}{$\begin{array}{l}\text { Engaged in an interlinked } \\
\text { relationship }\end{array}$} & $0.08^{* *}$ & $\begin{array}{c}-0.18(-0.12+0.08- \\
0.14)^{* * *}\end{array}$ & -0.26 \\
\hline \multirow{2}{*}{$\begin{array}{l}\text { Notengaged in an interlinked } \\
\text { relationship }\end{array}$} & $(0.02)$ & $(0.00)$ & $(0.90)$ \\
\hline \multirow{2}{*}{$\begin{array}{l}\text { Effect of being in an interlinked } \\
\text { relationship }\end{array}$} & $0.08^{* *}$ & -0.12 & -0.12 \\
\hline \multicolumn{2}{|c|}{$(0.02)$} & $(0.20)$ & $(0.20)$ \\
\cline { 2 - 4 } & Differential effect of the road & $-0.06^{* * *}$ & \\
\cline { 2 - 4 } & $(0.00)$ & -0.14 \\
\hline
\end{tabular}

Robust standard errors, clustered by villages calculated. P-values in parentheses ${ }^{* * *} p=0.01,{ }^{* *} p=0.05,{ }^{*} p=0.1$ 
Column 1 starts by looking at the aggregate data. Being in an interlinked relationship is found to have an insignificant impact on the households' chances of receiving public provision. Once again this may be due to the results being averaged out in the aggregate data. ${ }^{82}$ Column 2 , therefore, looks at data restricted to landlord-dominated villages only. I find that being in an interlinked relationship in an isolated landlord-dominated village reduces the households' chances of benefitting from public resources by $18 \%{ }^{83}$ Moreover, looking at partial effects in Table 5 .a. we can see from Column 2 that in isolated villages, households engaged in an interlinked relationship, are 6\% less likely to enjoy public provision when compared to those having single dealings with the landlord (significant at the 1\% level). Interestingly, from Table 5 we can see that, within connected landlorddominated villages, households engaged in an interlinked relationship are $8 \%$ more likely to benefit from state provision (significant at the $5 \%$ level). ${ }^{84}$ This is in line with hypothesis 2 as these are households who were most exploited when isolated. Therefore, they are most likely to exercise their exit options and thus need strong incentives to continue engaging with the landlord. Hence while landlords ignore households over whom they significant control in their contract with the politician, once connected landlords wanting to maintain their interaction with peasants are forced to channel public funds towards their clients.

\section{Conclusion}

Literature on rural development documents the importance of public provision in reducing inequality. While efforts have been made by governments to improve provision and combat

\footnotetext{
${ }^{82}$ Looking at interlinkages in rural Punjab, Author (2012a) finds this structure to be particularly exploitative in isolated landlord-dominated villages as peasants here lack outside options.

${ }^{83}$ The full effect of the interaction term is $-0.12+0.08-0.14$.

${ }^{84}$ The inclusion of the interaction term in a logistic regression means that the variable for interlinkages captures the effect of the relationship in connected villages. This is because it assumes that the variable for distance is 0 .
} 
corruption, elite-capture and patronage politics have often stood in the way of the desired results. This paper focused on the political aspects of the "lopsided friendship" 85 between landlords and peasants and the consequent outcomes in terms of public provision in the rural economy. It showed that the presence of clientelism erodes politicians' incentive to provide for their constituents directly, as they are able to guarantee success by contracting with local patrons. As a result, public provision to peasants is largely dependent on their bargaining power vis-à-vis their patron. Yet, large scale inequality, combined with isolation, has meant that patrons often enjoy considerably higher bargaining power and are therefore able to direct most public funds towards themselves.

Connecting isolated villages to the wider national economy through road networks was found to be one way of increasing the bargaining power of peasants. The link-roads connected to the motorway have led to a significant increase in traffic passing through villages, thereby increasing peasants’ mobility and employment opportunities. While most households did not choose to seek employment outside the village, these new options made peasants feel less dependent on the patron and thus enabled them to question why their votes were not translating into increased public provision.

Ten years after the construction of the motorway I find it to have strong spill-over effects on social dynamics within the villages. The breakdown of patrons' monopoly/monopsony power has led to an increase in the bargaining power of peasants, which they are now able to use for making demands on their patron. This can be seen through the higher levels of provision enjoyed by villagers close to the motorway. These benefits are being felt most strongly by the landless and socially lower classes who are most vulnerable in village society. Thus the evidence lends support to the claim that connectivity has altered the nature of the clientelist relationship, from one which was based on exploitation to one that is more cooperative in nature.

Even though the analysis is based on rural communities operating within (weak) democratic institutions, the results may also be applicable to urban communities and non-democratic regimes.

\footnotetext{
${ }^{85}$ Pitt-Rivers 1954, 140.
} 
While the urban poor are never as isolated as their rural counterparts, they too need to align with local brokers who may take advantage of their clients’ poverty. ${ }^{86}$ Moreover, in non-democratic regimes, clientelist exchanges would entail brokers offering support for the regime and suppression of revolts or uprisings in exchange for public resources. ${ }^{87}$ Therefore, while it would have to be subject to further study, the results of this paper may provide foundational insights on political clientelism in a wide range of contexts.

Even without applying this to urban and autocratic contexts, the policy implication drawn from this study is clear: when politics is dominated by clientelism, "exit has an essential role to play in restoring quality performance of government...". ${ }^{88}$ More specifically, it is imperative to connect rural villages to the outside economy so as to break their isolation and thus reduce the exploitative powers of resource rich patrons. Road networks are one way of achieving this. Aside from providing rural economies with much needed infrastructural development, such policies are not politically contentious, thereby making them easier to implement. This is not to say that building roads provides a silver bullet. However, what the road has done is to provide the stimuli needed to change power dynamics within rural villages which, in turn, enables villagers to start demanding their political rights. It can, therefore, be considered as a first step on the long road to development.

\footnotetext{
${ }^{86}$ See for example Kitschelt and Wilkinson 2007.

${ }^{87}$ See for example Birney 2014.

${ }^{88}$ Hirschman 1970, 117.
} 


\section{Bibliography}

Ahmad, Saghir. 1977. Class and power in a Punjabi village. New York: New York Monthly Review Press.

Alavi, Hamza. 1972. Kinship in West Punjab Villages. Contributions to Indian Sociology 6:1-27. Auyero, Javier. 1999. 'This is a lot like the Bronx, isn’t it?' Lived experiences of marginality in an Argentine slum. International Journal of Urban and Regional Research 23 (1):45-69.

Repeated Author. 2000. The Logic of Clientelism in Argentina: An Ethnographic Account. Latin American Research Review 35 (3):55-81.

Bailey, Frederick G. 1957. Caste and The Economic Frontier; A Village In Highland Orissa. Manchester: Manchester University Press.

Banerjee, Abhijit, and Lakshmi iyer. 2005. History, Institutions, and Economic Performance: The Legacy of Colonial Land Tenure Systems in India. The American Economic Review 95 (4):1190-1213.

Bardhan, Pranab. 1980. Interlocking Factor Markets and Agrarian Development: A Review of Issues. Oxford Economic Papers 32 (1):82-98.

Basu, Kaushik. 1986. One Kind of Power. Oxford Economic Papers 38:259-282.

Bhaduri, Amit. 1977. On the formation of usurious interest rates in backward agriculture. Cambride Journal of Economics 1 (4):341-352.

Birney, Mayling. 2014. Decentralization and Veiled Corruption Under China’s Rule of Mandates. World Development 52:55-67.

Brusco, Valeria, Marcelo Nazareno, and Susan stokes. 2002. Vote Buying in Argentina. Latin American Research Review 39:66-88.

Camp, Edwin. 2012. Animating the Machine, Yale University.

Cheema, Ali, and Shandana Mohmand. 2008. Decentralization and Inequality in Pakistan: Bridging the Gap that Divides. In Devolution and Governance Reforms in Pakistan, edited by Majad Saqib and S. M. Ali. Karachi: OUP. 
Repeat Authors. 2005. Provision Responses to Devolved Service Delivery - Case Evidence from Jaranwala Tehsil. edited by LUMS-McGill Social Enterprise Development Programme. Lahore University of Management Sciences.

Dasgupta, Partha. 1993. An inquiry into well-being and destitution. Oxford: Clarendon Press.

Eisenstadt, S. N., and Louis Roniger. 1980. Patron--Client Relations as a Model of Structuring Social Exchange. Comparative Studies in Society and History 22 (1):42-77.

Faguet, Jean-Paul. 2012. Decentralization and popular democracy: governance from below in Bolivia. Ann Arbor, USA.: University of Michigan Press.

Faguet, J. P, and Mahvish Shami. 2015. Instrumental Incoherence in Institutional Reform:

Decentralization as a Structural Solution to Political Exigency. In LSE ID Working Paper: LSE.

Fox, Jonathan. 1994. The Difficult Transition from Clientelism to Citizenship: Lessons from Mexico. World Politics 46 (2):151-184.

Gazdar, Harris. 2000. State, Community, and Universal Education: a Political Economy of Public Schooling in Rural Pakistan, London School of Economics and Political Science, London. GHK. 2005. Local Government in Pakistan: An Organisational and Institutional Analysis, Evidence from Hafizabad District. Hafizabad: Japan International Cooperation Agency.

Herring, Ronald J. 2005. Beyond The Political Impossibility Theorem of Agrarian Reform. In Changing paths: international development and the new politics of inclusion, edited by $\mathrm{P}$. Houtzager and M. Moore. Ann Arbor: University of Michigan Press.

Hirschman, Albert O. 1970. Exit, Loyalty, and Voice: Responses to Decline in Firms, Organizations, and States. Cambridge, MA: Harvard University Press.

Keefer, Philip. 2004. Clientelism, Credibility and Democracy. In Development Research Group. Washington DC: World Bank.

Repeated Author. 2007. Insurgency and credible commitment in autocracies and democracies. Washington DC: World Bank. 
Kitschelt, Herbert, and Steven Wilkinson. 2007. Patrons, Clients and Policies: Patterns of

Democratic Accountability and Political Competition. Cambridge University Press;.

Kurosaki, Takashi. 2007. Community and Economic Development in Pakistan: The Case of Citizen Community Boards in Hafizabad and Japanese Perspectives. Pakistan Development Review 45 (4).

Levitsky, Steven. 2001. Organization and Labor-Based Party Adaptation: The Transformation of Argentine Peronism in Comparative Perspective. World Politics 54 (01):27-56.

Mason, David. 1986. Land Reform and the Breakdown of Clientelist Politics in El Salvador. Comparative Political Studies 18 (4).

Mason, David, and Madhav Joshi. 2008. Between Democracy and Revolution: Peasant Support for Insurgency versus Democracy in Nepal Journal of Peace Research 45.

Medina, Luis Fernando, and Susan Stokes. 2007. Monopoly and Monitoring: An Approach to Political Clientelism. In Patrons, Clients and Policies: Patterns of Democratic Accountability and Political Competition, edited by H. Kitschelt and S. Wilkinson: Cambridge University Press.

Nelson, Matthew J. 2011. In the Shadow of Shari'ah: Islam, Islamic Law, and Democracy in Pakistan C Hurst \& Co Publishers Ltd.

Pitt-Rivers, Julian. 1954. The People of the Sierra. New York: Criterion Books.

Platteau, Jean-Philippe. 1995. An Indian Model of Aristocratic Patronage. Oxford Economic Papers 47 (4):636-662.

Powell, John D. 1970. Peasant Society and Clientelist Politics. American Political Science Review 64 (2):411-425.

Prat, Andrea, and David Strömberg. 2006. Commercial Television and Voter Information. UCLA, Deparment of Economics.

Rashid, Shaikh M. 1985. Land Reforms in Pakistan. Social Scientist 13 (9):44-52. 
Republic Engineering Cooperation. 1988. Lahore-Islamabad Motorway Project; Route Selection Study. edited by P. H. Authority. Lahore, Government of Punjab.: Government of Punjab. Roniger, Luis. 2004. Political Clientelism, Democracy, and Market Economy. Comparative Politics 36 (3):353-375.

Rouse, Shahnaz. 1988. Agrarian Transformation in a Punjabi Village: Structural Change and its Consequences, University of Wisconsin, Madison.

Schmidt, S. W., James Scott, Lande Carl, and Laura Guasti. 1977. Friends, Followers, and Factions: University of California Press

Scott, James C. 1972. Patron-Client Politics and Political Change in Southeast Asia. The American Political Science Review 66 (1):91-113.

Scott, James C, and Benedict J Kerkvliet. 1977. How traditional rural Patrons lose Legitimacy: A theory with Special Reference to Southeast Asia. In Friends, Followers and Factions: Reader in Political Clientelism, edited by S. W. Schmidt: University of California Press Shami, Mahvish. 2012. Collective action, clientelism, and connectivity. American Political Science Review 106 (03):588-606.

Repeated Author. 2012. The impact of connectivity on market interlinkages: evidence from rural Punjab World Development. World Development 40 (5):999-1012.

Shami, Mahvish, and Hadia Majid. 2014. The Political Economy of Public Goods Provision in Slums. In IGC working paper: IGC.

Stokes, Susan. 2004. Vote Buying in Argentina. Latin American Research Review 39 (2):66-88.

Stokes, Susan C, Thad Dunning, Marcelo Nazareno, and Valeria Brusco. 2013. Brokers, voters, and clientelism: The puzzle of distributive politics: Cambridge University Press.

Waterbury, John. 1977. An Attempt to Put Patrons and Clients in Their Place. In Patron and Clients in Mediterranean Societies, edited by E. Gellner and J. Waterbury.

Weingrod, Alex, and Emma Morin. 1971. Post Peasants: The Character of Contemporary Sardinian Society. Comparative Studies in Society and History 13 (3):301-324. 


\section{Interview list: ${ }^{89}$}

Chaudry Muhammad Altaf, Chairman National Highway Authority, interview, Lahore, 15 April 2008.

Household ID 45, interview, isolated landlord-dominated Village 1, May 16, 2008.

Household ID 258 connected landlord-dominated village 1, May 32008.

Household ID 266 connected landlord-dominated village 1, May 32008.

Household ID286, interview, isolated landlord-dominated Village 2, May 24, 2008.

Household ID 386, interview, connected landlord-dominated village 2, 23 May, 2008.

Landlord 1, interview, connected landlord-dominated Village 1, 15 April, 2008.

Landlord 1, interview, connected landlord-dominated Village 1, 3 May, 2008.

Landlord 2, interview, isolated landlord-dominated village 2, 24 May, 2008.

Key respondent 2, interview, isolated landlord-dominated village, May 16, 2008.

${ }^{89}$ These interviews were also used in author (2012a) and author (2012b). 


\section{Appendix}

Table 1A: Does the household have any public good provided to it?

\begin{tabular}{lcc}
\hline Public provision pre motorway & 1 & 2 \\
\hline Household is situated far from the & $\begin{array}{c}\text { Landlord- } \\
\text { Dominated } \\
\text { Villages }\end{array}$ & $\begin{array}{c}\text { Peasant- } \\
\text { Based } \\
\text { Villages }\end{array}$ \\
motorway & -0.09 & 0.003 \\
Household has access to a & $(0.18)$ & $(0.77)$ \\
newspaper & -0.005 & 0.07 \\
Upper class households & $(0.4)$ & $(0.3)$ \\
Lower class households & $0.15^{* * *}$ & 0.008 \\
& $(0.01)$ & $(0.93)$ \\
\hline $\mathrm{N}$ & -0.09 & 0.06 \\
Pseudo $\mathrm{R}^{2}$ & $(0.45)$ & $(0.55)$ \\
\hline Robust standard errors, clustered by villages, calculated. P-values in parentheses \\
$* * * \mathrm{p}<0.01, * * \mathrm{p}<0.05, * \mathrm{p}<0.1$
\end{tabular}

Figure 1A: Provision Levels of Drains and Paved Streets

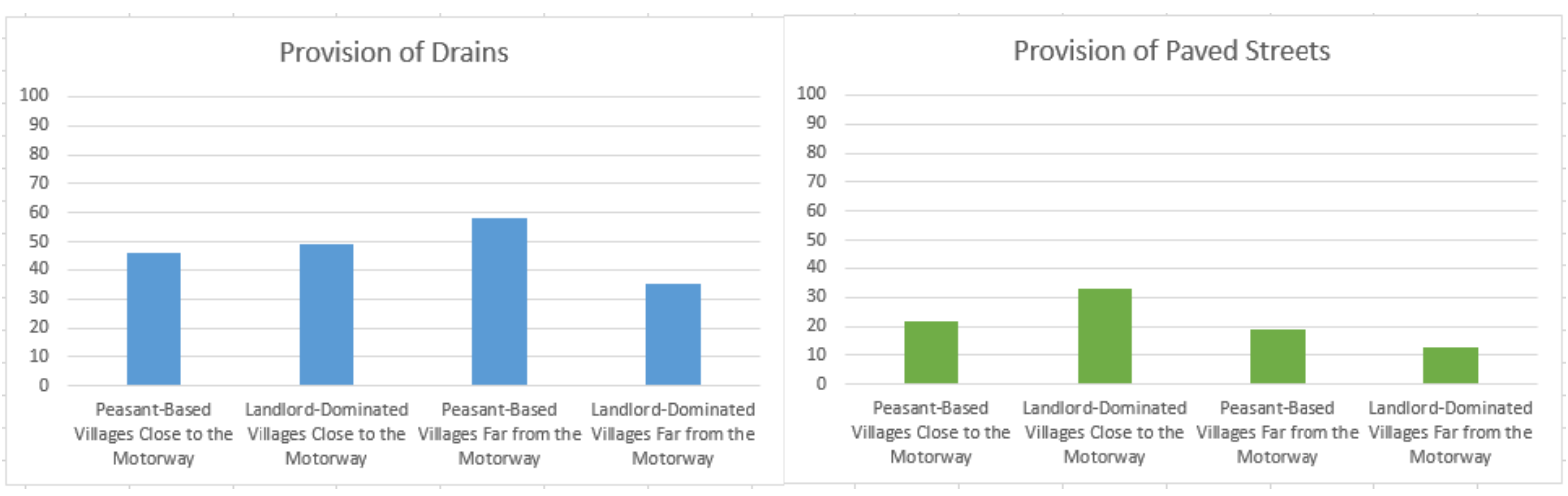

